\title{
IMPLEMENTASI PER-19/PJ/2014 TERHADAP TARIF PAJAK PENGHASILAN ORANG PRIBADI DAN KEPATUHAN PAJAK
}

Titin Fachriah Nur ${ }^{1}$

${ }^{1}$ Laboratorium Perpajakan, Program Vokasi UI, titinfachriahnur@yahoo.com

Diterima : 30 Maret 2014

Layak Terbit : 1 Juli 2014

\begin{abstract}
Abstrak
Sistem pengenaan pajak berdasarkan UU Nomor 36 tahun 2008 tentang Pajak Penghasilan menempatkan keluarga sebagai satu kesatuan ekonomis, yang artinya penghasilan atau kerugian dari seluruh anggota keluarga digabungkan sebagai satu kesatuan yang dikenai pajak dan pemenuhan kewajiban pajaknya dilakukan oleh kepala keluarga. Dalam hal tertentu pemenuhan kewajiban perpajakan suami istri dilakukan secara terpisah. Kurangnya pengetahuan perpajakan dapat mengakibatkan wajib pajak dianggap memilih menjalankan hak dan kewajiban perpajakan secara tersendiri. Pajak berdasarkan penggabungan penghasilan neto suami isteri pada kondisi tertentu mengakibatkan suami atau istri menanggung beban pajak diatas tarif lapisan jika pajak dihitung secara individu. Terdapat banyak hasil penelitian yang mengkaji peran tarif terhadap kepatuhan wajib pajak. Terdapat perbedaan hasil studi eksperimen dengan hasil penelitian empiris, yang diduga disebabkan oleh sifat pendapatan kena pajak.
\end{abstract}

Kata Kunci : Memilih Terpisah, Tarif PPh Orang Pribadi, Kepatuhan Pajak

\begin{abstract}
The taxation system is based on Law No. 36 of 2008 on Income Tax putting economical family as a unit, which means that the income or loss of all family members are combined as a single entity that is taxed and fulfillment of tax obligations made by the head of the family. In certain cases the fulfillment of tax obligations of husband and wife carried out separately. This lack of knowledge can lead to tax the taxpayer is considered choosing the rights and obligations of taxation in isolation. Net of income taxes based on the incorporation of a husband and wife in certain circumstances lead to a husband or wife to bear the tax burden on the tax rate if the layer is calculated individually. There is a lot of research that examines the role of tariffs on tax compliance. There are differences in the results of experimental studies with empirical research results, which is thought to be caused by the nature of the taxable income.
\end{abstract}

Keywords: Choosing Separately, Personal Income Tax Rates, Tax Compliance

\section{PENDAHULUAN}

\section{Latar Belakang}

Target penerimaan pajak tahun 2015 dalam APBNP 2015 adalah sebesar Rp 1.489 .3 triliun. Dalam lima tahun terakhir, target penerimaan pajak belum pernah tercapai. Realisasi APBNP tertinggi pada tahun 2011, yaitu sebesar 99,45\%, sedangkan realisasi terendah pada tahun 2013, yang hanya mencapai 72,57\%. Tahun 2014, dari jumlah APBNP sebesar Rp 1.246 triliun dapat terealisasi sebesar Rp 1,143 triliun (91,75\%). Langkah yang dilakukan pemerintah untuk dapat mempertahankan penerimaan pajak antara lain melakukan intensifikasi dan ekstensifikasi pajak. Intensifikasi pajak berupa perbaikan internal pada Direktorat Jenderal Pajak, sementara langkah ekstensifikasi berupa program sensus pajak, sinkronisasi eKTP dengan NPWP, pengenaan pajak pada sektor UKM dan pendataan ulang barang kena pajak.

Upaya ekstensifikasi tersebut berdampak pada meningkatnya basis pajak atau jumlah wajib pajak. Berdasarkan data Kementrian Keuangan, basis pajak di Indonesia saat ini mencapai 20 juta wajib pajak yang sebelumnya berjumlah empat sampai lima juta wajib pajak. Peningkatan basis pajak tersebut tentunya harus diikuti dengan peningkatan kepatuhan pajak. Pada tabel 1. 
Data Wajib Pajak dan Kepatuhan Pajak, terlihat rasio kepatuhan pajak selama lima tahun terakhir mempunyai trend naik turun. Bahkan dalam rentang waktu tersebut, realisasi kepatuhan yang melebihi targetnya hanya terjadi di tahun 2010. Jika dibandingkan dengan tahun sebelumnya, rasio kepatuhan tahun 2014 turun sebesar 2,07\%, keluarga. Dalam hal tertentu pemenuhan kewajiban perpajakan dilakukan secara terpisah : Sebagai langkah ekstensifikasi, pemerintah ingin memaksimalkan informasi penghasilan wajib pajak dengan cara mengintegrasikan data-data anggota keluarga sesuai dengan Nomor Induk Kependudukan (NIK).

Tabel 1.

Data Wajib Pajak \& Kepatuhan Pajak

\begin{tabular}{lrrrrr}
\hline \multicolumn{1}{c}{ Deskripsi } & \multicolumn{1}{c}{2010} & \multicolumn{1}{c}{2011} & \multicolumn{1}{c}{2012} & \multicolumn{1}{c}{2013} & \multicolumn{1}{c}{2014} \\
\hline WP Terdaftar dan Wajib SPT & 14.101 .933 & 17.694 .317 & 17.659 .278 & 17.731 .736 & 18.357 .833 \\
Tahunan & & & & & \\
SPT Tahunan PPh yang masuk & 8.202 .309 & 9.331 .616 & 9.482 .480 & 10.781 .105 & 10.781 .720 \\
Rasio Kepatuhan & 58,16 & 52,74 & 53,44 & 60,80 & 58,73 \\
Target Rasio Kepatuhan & 57,50 & 62,50 & 62,50 & NA & $70 \%$ \\
\hline
\end{tabular}

Sumber : Departemen Keuangan Republik Indonesia Direktorat Jenderal Pajak, data diolah

Pada banyak penelitian sebelumnya tarif pajak merupakan salah satu faktor yang mempengaruhi tingkat kepatuhan wajib pajak. Artikel ini akan menganalisa dampak dikeluarkannya PER-19/PJ. 2014 terhadap tarif $\mathrm{PPh}$ Gabungan dan dampaknya pada tingkat kepatuhan wajib pajak orang pribadi.

Bulan Juli 2014, pemerintah mengeluarkan aturan baru mengenai pengisian Surat Pemberitahuan Pajak Penghasilan (SPT PPh) Orang Pribadi melalui peraturan Direktur Jendral Pajak Nomor PER- 19/PJ/2014 tentang Perubahan kedua atas peraturan Direktur Jendral Pajak Nomor PER34/PJ/2010 tentang bentuk formulir surat pemberitahuan tahunan pajak penghasilan wajib pajak orang pribadi dan wajib pajak badan beserta petunjuk pengisiannya. Pokokpokok perubahan SPT PPh OP dan WP antara lain pencantuman data Nomor Induk Kependudukan, Kode Daftar Harta dan Kewajiban, Status Perpajakan Kepala Keluarga dan Penghitungan Penghasilan Gabungan antara suami dan istri yang memilih untuk menjalankan kewajiban perpajakan secara terpisah.

Sistem pengenaan pajak berdasarkan UU Nomor 36 tahun 2008 menempatkan keluarga sebagai satu kesatuan ekonomis, yang artinya penghasilan atau kerugian dari seluruh anggota keluarga digabungkan sebagai satu kesatuan yang dikenai pajak dan pemenuhan kewajiban pajaknya dilakukan oleh kepala
Langkah tersebut akan memudahkan penelusuran besarnya penghasilan yang diterima oleh anggota keluarga, yang terdiri dari kepala keluarga, istri dan anak. Pemotong penghasilan wajib mencatumkan pula NIK penerima penghasilan. Fiskus dapat dengan mudah melakukan penelusuran besarnya penghasilan yang dilaporkan oleh wajib Pajak melalui SPT Tahunan WPOP dengan membandingkannya dengan SPT Masa Pemotong yang berisi besarnya pajak penghasilan yang telah dipotong pph pasal 21 . Jika dalam satu tahun pajak wajib pajak menerima penghasilan dari lebih dari satu pemberi kerja, atas gabungan penghasilan tersebut akan terdapat pajak yang kurang dibayar pada akhir tahun.

Pada ulasan ini penulis ingin membahas mengenai bagaimana penerapan perhitungan suami istri yang dianggap memilih perhitungan MT, misalnya dalam kondisi istri berpenghasilan dari satu pemberi kerja namun telah memiliki NPWP dan pada saat pelaporan SPT WPOP tahun 2014 belum mencabut NPWP nya. Selanjutnya atas penggabungan penghasilan suami dan istri, apakah terdapat pengaruh kepada lapisan tarif sesuai pasal 17 UU No. 36 tahun 2008?

\section{Metode Penelitian}

OECD (2011) membagi kepatuhan pajak kedalam kategori kepatuhan administratif dan 
kepatuhan teknis. Kepatuhan administratif berbentuk kepatuhan terhadap aturan yang bersifat adminsitratif, yaitu pelaporan dan prosedur. Sedangkan kepatuhan teknis berhubungan dengan teknis penghitungan pajak, misalnya jumlah pajak yang dibayarkan telah sesuai dengan ketentuan perpajakan. Luigi Alberto Franzoni (1999) menyebutkan kepatuhan atas pajak (tax compliance) adalah melaporkan penghasilan sesuai dengan peraturan pajak, melaporkan Surat Pemberitahuan (SPT) dengan tepat waktu dan membayar pajak tepat waktu. Norman D. Nowak mengemukakan kepatuhan perpajakan sebagai "suatu iklim" kepatuhan dan kesadaran pemenuhan kewajiban perpajakan yang tercermin dalam (Devano, 2006:110) pemahaman wajib pajak terhadap ketentuan perundangan, pengisian formulir pajak lengkap dan jelas, jumlah pajak dihitung dengan benar dan pembayaran pajak tepat waktu. Menurut Nurmantu (2003:148) kepatuhan pajak adalah keadaan dimana wajib pajak memenuhi semua kewajiban dan melaksanakan hak perpajakannya.

\section{Kepatuhan Pajak dan Tarif Pajak}

Terdapat beberapa kajian mengenai hubungan kepatuhan dengan tarif yang antara lain berupa riset eskperimen yang dilakukan oleh Collins and Plumplee, 1991; Moser, Evans dan Kim (1995). Kajian tersebut berkesimpulan bahwa peningkatan tarif pajak berdampak negative atau tidak berpengaruh kepada kepatuhan wajib pajak. Clotfelter (1983) membuat model non compliance berdasarkan tiga kelas, yaitu non bisnis, bukan bisnis pertanian dan bisnis pertanian, kemudian menguji dampak marginal tax rate dan tingkat penghasilan kepada non compliance. Hasilnya pendapatan dan tarif pajak berhubungan negative dengan tingkat kepatuhan.

Namun terdapat penelitian dengan hasil yang berbeda, yang dilakukan oleh Allingham dan Sandmo (1972). Menurutnya tingkat kapatuhan seharusnya meningkat seiring dengan peningkatan tarif pajak. Feinstein (1991) dan Andreoni et $\mathrm{Al}$ (1998) juga menunjukkan hubungan yang positif antara tarif dan kepatuhan pajak

Komalasari dan Nashih mengutip Alm. Jackson dan McKee (1992) yang melakukan studi eksperimental untuk menentukan determinan kepatuhan wajib pajak. Jika dibandingkan dengan probabilitas audit dan penalty, peningkatan kepatuhan akan lebih besar ketika individu menghadapi tarif pajak yang lebih rendah dan ketika menerima sesuatu atas pajak yang telah dibayarkan. Komalasari dan Nashih (2005) menguji hubungan antara tarif pajak dan kepatuhan dan bagaimana hubungan tersebut dipengaruhi oleh jenis income, yaitu endowed income dan earned income. Ketika wajib pajak menerima endowed income tidak terdapat perbedaan tingkat kepatuhan wajib pajak baik dalam kondisi tarif pajak yang berlaku tinggi atau rendah. Hasil penelitian tersebut berbeda dengan Boylan dan Sprinkle (2001) dan Moser et al (1995). Sedangkan penerima penghasilan earned income, tingkat kepatuhan wajib pajak menunjukkan hasil yang sama dengan Boylan dan Sprinkle (2001) dam Allingham dan Sandmo (1972).

Penelitian tentang kepatuhan pajak terdahulu dilakukan melalui kajian riset dengan berbagai metodologi. Pada artikel ini penulis menggunakan metode deskriptif, yaitu metode yang tidak dimaksudkan untuk menguji hipotesis tertentu, hanya menggambarkan tentang suatu variable, gejala atau keadaan (Suharsimi Arikunto). Diperoleh akan analisis, sehingga dapat ditarik kesimpulan yang menggambarkan hasil dari analisis tersebut.

\section{HASIL DAN PEMBAHASAN}

Besarnya penghasilan kena pajak bagi wajib pajak orang pribadi dalam negeri dihitung dengan mengurangkan penghasilan neto dengan jumlah Penghasilan Tidak Kena Pajak (PTKP) pasal 7 UU No. 36 tahun 2008. Besarnya PTKP disesuaikan dengan mempertimbangkan kondisi perekonomian serta kebutuhan pokok setiap tahun dan ditetapkan setelah berkonsultasi dengan DPR RI. Penyesuaian besarnya PTKP terakhir telah diubah dengan Peraturan Menteri Keuangan Nomor 162/PMK.011/2012 tentang penyesuaian besarnya penghasilan tidak kena pajak (Surat Edaran Dirjen Pajak Nomor SE-51/PJ/2012 yang berlaku mulai tanggal 1 Januari 2013, yaitu :

a. Rp 24.300.000,- untuk diri sendiri wajib pajak orang pribadi

b. Rp. 2.025.000,- tambahan untuk wajib pajak kawin

c. Rp 24.300.000,- tambahan untuk seorang istri yang penghasilannya digabung 
dengan penghasilan suami sebagaimana dimaksud dalam pasal 8 ayat (1)

d. Rp. 2.025.000,- tambahan untuk setiap anggota keluarga sedarah dan keluarga semenda dalam garis keturunan lurus serta anak angkat, yang menjadi tanggungan sepenuhnya, paling banyak 3 (tiga) orang untuk setiap keluarga

Atas penghasilan kena pajak bagi wajib pajak orang pribadi dikenakan tarif progresif sesuai dengan lapisan tarif yang diatur dalam UU Nomor 36 Tahun 2008 tentang Pajak Penghasilan Pasal 17, ayat 1 huruf a. Tarif pajak yang diterapkan atas penghasilan Kena Pajak bagi Wajib Pajak orang pribadi dalam negeri adalah sebagai berikut : tahun sebelumnya yang belum dikompensasikan sebagaimana dimaksud dalam pasal 6 ayat 2 dianggap sebagai penghasilan atau kerugian suaminya, kecuali penghasilan tersebut semata-mata diterima atau diperoleh dari satu pemberi kerja yang telah dipotong pajak berdasarkan ketentuan pasal 21 dan pekerjaan tersebut tidak ada hubungannya dengan usaha atau pekerjaan bebas suami atau anggota keluarga lainnya.

Tabel 2.

Tarif Pajak Orang Pribadi

\begin{tabular}{lc}
\hline \multicolumn{1}{c}{ Lapisan Penghasilan Kena Pajak } & Tarif pajak \\
\hline Sampai dengan Rp 50.000.000,-- & $5 \%$ \\
Diatas Rp 50.000.000,- sd Rp 250.000.000,- & $15 \%$ \\
Diatas Rp 250.000.000,- sd Rp 500.000.000,- & $25 \%$ \\
Diatas Rp 500.000.000 & $30 \%$ \\
\hline
\end{tabular}

Sumber : Pasal 17 UU no 36 tahun 2008]

Sistem pengenaan pajak berdasarkan UU Nomor 36 tahun 2008 menempatkan keluarga sebagai satu kesatuan ekonomis, yang artinya penghasilan atau kerugian dari seluruh anggota keluarga digabungkan sebagai satu kesatuan yang dikenai pajak dan pemenuhan kewajiban pajaknya dilakukan oleh kepala keluarga. Dalam hal tertentu pemenuhan kewajiban perpajakan suami istri dilakukan secara terpisah.

Penerapan perhitungan suami istri yang dianggap memilih perhitungan Memilih Terpisah

Pasal 8 UU Nomor 36 tahun 2008 mengatur sebagai berikut :

Ayat 1

Seluruh penghasilan atau kerugian bagi wanita yang telah kawin pada awal tahun pajak atau pada awal bagian tahun pajak, begitu pula kerugiannya yang berasal dari tahun-
Ayat 2

Penghasilan suami-istri dikenai pajak secara terpisah apabila :

a. Suami istri telah hidup berpisah berdasarkan putusan hakim;

b. Dikehendaki secara tertulis oleh suami-istri berdasarkan perjanjian pemisahan harta dan penghasilan; atau

c. Dikehendaki oleh istri yang memilih untuk menjalankan hak dan kewajiban perpajakannya sendiri

Ayat 3

Penghasilan neto suami istri sebagaimana dimaksud pada ayat 2 huruf b dan huruf c dikenai pajak berdasarkan penggabungan penghasilan neto suami-istri dan besarnya pajak yang harus dilunasi oleh msing-masing suami-istri 
dihitung sesuai dengan perbandingan penghasilan neto mereka.

\section{Ayat 4 \\ Penghasilan anak yang belum dewasa digabung dengan penghasilan orang tuanya}

Contoh penghitungan pajak pada ketentuan di atas : Wajib Pajak A memperoleh penghasilan neto dari usaha sebesar Rp 100 juta, mempunyai istri yang menjadi pegawai dengan penghasilan neto sebesar Rp 70 juta.

- Jika penghasilan istri diperoleh dari satu pemberi kerja dan telah dipotong pajak oleh pemberi kerja dan pekerjaan tersebut tidak ada hubungannya dengan usaha suami atau anggota keluarga lainnya, penghasilan neto istri tidak digabung dengan penghasilan A dan pengenaan pajak atas penghasilan istri bersifat final.

- Jika selain menjadi pegawai, istri A juga menjalankan usaha lainnya dengan penghasilan neto sebesar Rp 80 juta, seluruh penghasilan istri digabungkan dengan penghasilan A. Pajak yang dikenakan atas penghasilan sebesar $\mathrm{Rp}$ 250 juta, dan atas pajak yang telah di potong dari penghasilan istri dapat dikreditkan dan dilaporkan dalam SPT PPh.

- Dalam kondisi seperti pada pasal 8 ayat 2 huruf a,b dan c UU No 36 tahun 2008, perhitungan pajaknya menjadi :

Suami : Rp 100 juta/250 juta x Rp

$27.550 .000=\operatorname{Rp} 11.020 .000,-$

Istri : $\mathrm{Rp} 150$ juta/250 juta $\mathrm{x} \quad \mathrm{Rp}$ 27.550.000 = Rp 16.530.000,-

Catatan : asumsi pajak atas penghasilan neto Rp 250 juta sebesar Rp 27.550.000,-

Ketentuan pelaksanaan kewajiban perpajakan secara terpisah antara suami dan istri diatur dengan Surat Edaran Dirjen Pajak No. SE-29/PJ/2010 tanggal 1 Maret 2010.

"Suami-isteri yang melakukan perjanjian pemisahan harta dan penghasilan atau isteri yang menghendaki berkeinginan untuk memilih dalam menjalankan hak dan kewajiban perpajakannya secara tersendiri (terpisah dari suami), akan dikenakan pajak berdasarkan penggabungan penghasilan neto suami isteri dan besarnya pajak yang harus dilunasi oleh masing-masing suami-isteri dihitung sesuai dengan perbandingan penghasilan neto mereka.

Bentuk Surat Pemberitahuan Tahunan Pajak Penghasilan yang didalamnya mengatur ketentuan di atas baru dikeluarkan pada bulan Juli 2014 untuk diterapkan pada SPT Tahunan WP Orang Pribadi tahun 2014, melalui Peraturan Dirjen Pajak Nomor PER19/PJ/2014. Lampiran IV PER-19/PJ/2014 merupakan Petunjuk Pengisian Pajak Penghasilan Orang Pribadi dengan formulir 1770 S. Formulir tersebut digunakan oleh wajib pajak yang mempunyai penghasilan dari satu atau lebih pemberi kerja; penghasilan dalam negeri lainnya, dan/atau penghasilan yang dikenakan $\mathrm{PPh}$ final dan atau bersifat final. Pada butir kedua petunjuk umum pengisian formulir tersebut diatur :

“ Penghasilan yang dikenai pajak penghasilan adalah penghasilan dari seluruh anggota keluarga wajib pajak yang digabungkan sebagai satu kesatuan dan pemenuhan kewajiban pajaknya dilakukan oleh wajib pajak sebagai kepala keluarga."

Penghasilan suami istri akan dikenai pajak secara terpisah apabila :

a) Suami istri telah hidup berpisah berdasarkan putusan hakim (HB);

b) Dikehendaki secara tertulis oleh suami istri berdasarkan perjanjian pemisahan harta dan penghasilan $(\mathrm{PH})$ atau

c) Dikehendaki oleh isteri yang memilih untuk menjalankan hak dan kewajiban perpajakannya sendiri (MT)

Pemenuhan kewajiban pajaknya dilakukan masing-masing oleh suami dan isteri secara terpisah. Dalam hal ini, isteri memiliki kewajiban mendaftarkan diri untuk diberikan NPWP sehingga menjadi Wajib Pajak Orang 
Pribadi tersendiri. Suami-isteri yang mempunyai penghasilan selain dari usaha dan/atau pekerjaan bebas dengan jumlah penghasilan bruto tidak lebih dari Rp60.000.000,00 (enam puluh juta rupiah) setahun, namun memiliki status perpajakan PH atau MT wajib melaporkan penghasilan dan penghitungan Pajak Penghasilan dengan menggunakan Fomulir SPT Tahunan $\mathrm{PPh}$ Orang Pribadi 1770 S, bukan menggunakan Formulir SPT Tahunan PPh Orang Pribadi $1770 \mathrm{SS}$

Tabel 3. Kasus 1, Penghasilan suami dan istri berada pada lapisan tarif pertama

\section{Pengaruh lapisan tarif sesuai pasal 17 UU No. 36 tahun 2008 sebagai dampak penggabungan penghasilan suami dan istri}

Jika istri memilih untuk menjalankan hak dan kewajiban perpajakannya sendiri (MT), maka pemenuhan kewajiban pajaknya dilakukan masing-masing oleh suami dan isteri secara terpisah.

\begin{tabular}{llll}
\hline & $\begin{array}{l}\text { Penghasilan } \\
\text { suami }\end{array}$ & Penghasilan Istri & $\begin{array}{l}\text { Penghasilan } \\
\text { Gabungan }\end{array}$ \\
\hline 1. Penghasilan Neto & 45.000 .000 & 45.000 .000 & 90.000 .000 \\
2. PTKP & $(28.350 .000)$ & $(24.300 .000)$ & $(52.650 .000)$ \\
3. PKP & 16.650 .000 & 20.700 .000 & 37.350 .000 \\
4. PPh & 832.500 & 1.035 .000 & \\
5. Alokasi pajak & 933.750 & 933.750 & 1.867 .500 \\
& & & 0 \\
\hline
\end{tabular}

Sumber : Pasal 17 UU No 36, 2008 data diolah

Tabel 4. Kasus 2, Penghasilan suami pada lapisan tarif kedua, istri lapisan tarif pertama

\begin{tabular}{llll}
\hline & $\begin{array}{l}\text { Penghasilan } \\
\text { suami }\end{array}$ & $\begin{array}{l}\text { Penghasilan } \\
\text { Istri }\end{array}$ & $\begin{array}{l}\text { Penghasilan } \\
\text { Gabungan }\end{array}$ \\
\hline $\begin{array}{l}\text { 1. Penghasilan Neto } \\
\text { 2. PTKP }\end{array}$ & $\begin{array}{l}\text { (28.350.0000) } \\
\text { 3. PKP }\end{array}$ & $\begin{array}{l}(24.300 .000) \\
\text { 7.000 }\end{array}$ & $(52.650 .000)$ \\
4. PPh & 71.650 .000 & 20.700 .000 & 92.350 .000 \\
5. Alokasi pajak & 6.105 .172 & 2.747 .328 & 8.852 .500 \\
Kurang bayar & & & 2.070 .000 \\
\hline
\end{tabular}

Sumber : Pasal 17 UU No 36, 2008 data diolah 
Dalam hal ini, isteri memiliki kewajiban mendaftarkan diri untuk diberikan NPWP sehingga menjadi Wajib Pajak Orang Pribadi tersendiri.

Bagaimana jika seorang istri hanya menerima penghasilan dari satu pemberi kerja, sebelum menikah telah terlebih dahulu memiliki NPWP atas namanya sendiri, atau sebelum ketentuan tersebut telah menikah dan mempunyai NPWP sendiri namun sebenarnya tidak beniat untuk memilih menjalankan kewajiban pajak suami istri secara terpisah.
Pada saat penyampaian SPT 2014 istri belum mencabut NPWP individu mengikuti NPWP suami, sehingga melakukan hak dan kewajiban perpajakan secara terpisah (MT). Berdasarkan pasal 8 dan penerapan lapisan tarif pasal 17 UU No 38 tahun 2008, penulis membuat simulasi perhitungan penggabungan penghasilan suami istri dengan lapisan tarif yang berbeda :

Tabel 5. Kasus 3, Penghasilan suami pada lapisan tarif ketiga, istri lapisan tarif pertama

\begin{tabular}{lccc}
\hline & $\begin{array}{l}\text { Penghasilan } \\
\text { suami }\end{array}$ & Penghasilan Istri & Penghasilan Gabungan \\
\hline 1. Penghasilan Neto & 300.000 .000 & 45.000 .000 & 345.000 .000 \\
2. PTKP & $(28.350 .000)$ & $(24.300 .000)$ & $(52.650 .000)$ \\
3. PKP & 271.650 .000 & 20.700 .000 & 292.350 .000 \\
4. PPh & 37.912 .500 & 1.035 .000 & \\
5. Alokasi pajak & 37.467 .391 & 5.620 .109 & 43.087 .500 \\
Kurang bayar & & & 4.140 .000 \\
\hline
\end{tabular}

Sumber : Pasal 17 UU No 36, 2008 data diolah

Tabel 6. Kasus 4, Penghasilan suami pada lapisan tarif keempat, istri lapisan tarif pertama

\begin{tabular}{llll}
\hline & $\begin{array}{l}\text { Penghasilan } \\
\text { suami }\end{array}$ & Penghasilan Istri & $\begin{array}{l}\text { Penghasilan } \\
\text { Gabungan }\end{array}$ \\
\hline 1. Penghasilan Neto & 600.000 .000 & 45.000 .000 & 645.000 .000 \\
2. PTKP & $(28.350 .000)$ & $(24.300 .000)$ & $(52.650 .000)$ \\
3. PKP & 571.650 .000 & 20.700 .000 & 592.350 .000 \\
4. PPh & 116.495 .000 & 1.035 .000 & \\
5. Alokasi pajak & 114.144 .186 & 8.560 .814 & 122.705 .000 \\
Kurang bayar & & & 5.175 .000 \\
\hline
\end{tabular}

Sumber : Pasal 17 UU No 36, 2008 data diolah 
Tabel 7. Kasus 5, Penghasilan suami pada lapisan tarif kedua, istri lapisan tarif kedua

\begin{tabular}{llll}
\hline & $\begin{array}{l}\text { Penghasilan } \\
\text { suami }\end{array}$ & Penghasilan Istri & $\begin{array}{l}\text { Penghasilan } \\
\text { Gabungan }\end{array}$ \\
\hline $\begin{array}{l}\text { 1. Penghasilan Neto } \\
\text { 2. PTKP }\end{array}$ & 100.000 .000 & 100.000 .000 & 200.000 .000 \\
3. PKP & $(28.350 .000)$ & $(24.300 .000)$ & $(52.650 .000)$ \\
4. PPh & 71.650 .000 & 75.700 .000 & 147.350 .000 \\
5. Alokasi pajak & 5.747 .500 & 6.355 .000 & 17.102 .500 \\
Kurang bayar & 8.551 .250 & 8.551 .250 & 5.000 .000 \\
\hline
\end{tabular}

Sumber : Pasal 17 UU No 36, 2008 data diolah

Tabel 8, Kasus 6, Penghasilan suami dan istri pada lapisan tarif ketiga

\begin{tabular}{llll}
\hline & $\begin{array}{l}\text { Penghasilan } \\
\text { suami }\end{array}$ & Penghasilan Istri & $\begin{array}{l}\text { Penghasilan } \\
\text { Gabungan }\end{array}$ \\
\hline 1. Penghasilan Neto & 300.000 .000 & 300.000 .000 & 600.000 .000 \\
2. PTKP & $(28.350 .000)$ & $(24.300 .000)$ & $(52.650 .000)$ \\
3. PKP & 271.650 .000 & 275.700 .000 & 547.350 .000 \\
4. PPh & 37.912 .500 & 38.925 .000 & \\
5. Alokasi pajak & 54.602 .500 & 54.602 .500 & 109.205 .000 \\
Kurang bayar & & & 32.367 .500 \\
\hline
\end{tabular}

Sumber : Pasal 17 UU No 36, 2008 data diolah

Tabel 9. Kasus 7, Penghasilan suami dan istri pada lapisan tarif ke empat

\begin{tabular}{lccc}
\hline & Penghasilan suami & Penghasilan Istri & $\begin{array}{l}\text { Penghasilan } \\
\text { Gabungan }\end{array}$ \\
\hline 1. Penghasilan Neto & 600.000 .000 & 600.000 .000 & 1.200 .000 .000 \\
2. PTKP & $(28.350 .000)$ & $(24.300 .000)$ & $(52.650 .000)$ \\
3. PKP & 571.650 .000 & 575.700 .000 & 1.147 .350 .000 \\
4. PPh & 116.495 .000 & 117.710 .000 & \\
5. Alokasi pajak & 144.602 .500 & 144.602 .500 & 289.205 .000 \\
Kurang bayar & & & 55.000 .000 \\
\hline
\end{tabular}

Sumber : Pasal 17 UU No 36, 2008 data diolah 
Asumsi dari seluruh perhitungan diatas adalah suami dan istri masing-masing memperoleh penghasilan dari satu pemberi kerja dan telah dipotong pajak penghasilan oleh pemberi kerja. Perhitungan pajak penghasilan suami dihitung dengan Penghasilan Tidak Kena Pajak status K/1, yaitu sebesar Rp 28.350.000,-, sedangkan istri dengan status TK, sebesar Rp 24.300.000,-. Perhitungan penghasilan kena pajak gabungan dihitung dengan status $\mathrm{K} / \mathrm{I} / 1$, yaitu sebesar Rp 52.650.000,-

Dari perhitungan dengan 7 (tujuh) kombinasi lapisan penghasilan kena pajak suami dan istri diatas, hubungan antara kenaikan pajak yang dihitung dengan penggabungan penghasilan suami dan istri jika dibandingkan dengan perhitungan pajak individu suami dan istri (kolom A dan B) serta kenaikan total kurang bayar (kolom C) adalah sebagai berikut :

Kasus 1, penghasilan kena pajak suami dan istri yang digabungkan masih berada pada lapisan tarif pertama. Tidak terdapat selisih perhitungan $\mathrm{PPh}$ pasal 21 antara pajak gabungan jika dibandingkan dengan pajak individu suami dan istri yang dihitung oleh masing-masing pemberi kerja. Pada kasus 2 $\mathrm{s} / \mathrm{d}$ 7, sebelum digabungkan penghasilan kena pajak suami dan istri berada pada lapisan tarif yang berbeda. Dampak setelah penghasilan digabungkan, terjadi kurang bayar pada penghasilan gabungan secara bervariasi (kolom C baris 2 sd 7). Hal ini disebabkan dengan penggabungan penghasilan kena pajak tersebut, pajak yang terhutang berada pada lapisan tarif yang lebih tinggi. Hal yang mendapat perhatian penulis adalah atas alokasi pajak gabungan istri (kolom B baris 2 sd 7) terjadi peningkatan kurang bayar yang cukup besar.

Tabel 10

Persentase Kenaikan Pajak Gabungan Dibandingkan dengan Pajak Individu Suami Istri

\begin{tabular}{|c|c|c|c|c|}
\hline & Kombinasi Penghasilan Kena Pajak & $\begin{array}{l}\% \text { alokasi pajak } \\
\text { gabungan suami } \\
\text { thd pajak } \\
\text { individu suami } \\
\text { (A) }\end{array}$ & $\begin{array}{l}\% \text { alokasi pajak } \\
\text { gabungan istri } \\
\text { thd pajak } \\
\text { individu istri } \\
\text { (B) }\end{array}$ & $\begin{array}{c}\% \text { total pajak } \\
\text { gabungan/jumlah } \\
\text { pajak individu } \\
\text { suami\&istri }(\mathrm{C})\end{array}$ \\
\hline 1. & $\begin{array}{l}\text { suami dan istri berada pada lapisan tarif } \\
\text { pertama }\end{array}$ & 112,16 & 90,22 & 100,00 \\
\hline 2. & $\begin{array}{l}\text { suami pada lapisan tarif kedua, istri lapisan } \\
\text { tarif pertama }\end{array}$ & 106,22 & 265,44 & 130,52 \\
\hline 3. & $\begin{array}{l}\text { suami pada lapisan tarif ketiga, istri lapisan } \\
\text { tarif pertama }\end{array}$ & 98,83 & 543,01 & 110,63 \\
\hline 4. & $\begin{array}{l}\text { suami pada lapisan tarif keempat, istri } \\
\text { lapisan tarif pertama }\end{array}$ & 97,98 & 827,13 & 104,40 \\
\hline 5. & $\begin{array}{l}\text { suami pada lapisan tarif kedua, istri lapisan } \\
\text { tarif kedua }\end{array}$ & 148,78 & 134,56 & 141,31 \\
\hline 6. & suami dan istri pada lapisan tarif ketiga & 144,02 & 140,00 & 142,12 \\
\hline 7. & suami dan istri pada lapisan tarif ke empat & 124,13 & 122,85 & 123,40 \\
\hline
\end{tabular}

Sumber : Berbagai sumber, Data diolah 
Penggabungan penghasilan kena pajak suami dan istri mengakibatkan penghasilan kena pajak istri dikenakan lapisan tarif sesuai dengan lapisan tarif penghasilan suami. Misalnya pada kasus 3, penghasilan kena pajak istri yang seharusnya dikenakan lapisan tarif $5 \%$, karena penghasilan kena pajak suami berada pada lapisan tarif ketiga , maka setelah digabungkan dengan penghasilan kena pajak gabungan dikenakan tarif $25 \%$. untuk suami (kolom A), istri (kolom B) dan gabungan (kolom C). Hutagaol, Winarno dan Pradipta (2007) mengkaji bahwa berdasarkan data dan informasi mengenai kepatuhan wajib pajak bahwa wajib pajak yang memiliki penghasilan yang semakin besar cenderung lebih patuh, penerapan tarif yang lebih rendah mendorong kepatuhan wajib pajak dibanding penerapan tarif yang lebih tinggi.

Tabel 4.

Perbandingan Tarif Pajak Penghasilan Orang pribadi anggota ASEAN

\begin{tabular}{|c|l|r|r|}
\hline No & \multicolumn{1}{|c|}{ Negara } & \multicolumn{2}{|c|}{$\begin{array}{c}\text { Tarif Pajak } \\
\text { Penghasilan } \\
\text { Orang Pribadi } \\
(\%) \mathrm{O}\end{array}$} \\
\hline 1 & Brunei Darussalam & & \\
\hline 2 & Cambodia & 0 & 20 \\
\hline 3 & Indonesia & 5 & 30 \\
\hline 4 & Lao PDR & 0 & 24 \\
\hline 5 & Malaysia & 20 & 30 \\
\hline 6 & Myanmar & 20 & 32 \\
\hline 7 & Philippine & 3,5 & 20 \\
\hline 8 & Sngapore & 5 & 37 \\
\hline 9 & Thailand & 5 & 35 \\
\hline 10 & Vietnam & & \\
\hline
\end{tabular}

Sumber : www.taxrates.cc/html......

Pada kasus 3, jumlah kurang bayar istri adalah sebesar 543,01\% jika dibandingkan pajak individu yang telah dipotong oleh pemberi kerja. Hal yang sama juga berlaku pada kasus 4, dimana jumlah kurang bayar istri adalah sebesar $827,13 \%$ jika dibandingkan pajak individu yang telah dipotong oleh pemberi kerja.

Pada kasus 5 s/d 7, sebelum digabungkan penghasilan kena pajak suami dan istri berada pada lapisan tarif yang sama, yaitu pada lapisan kedua, ketiga dan keempat. Dampak setelah penghasilan kena pajak digabungkan, terjadi kurang bayar pada penghasilan gabungan secara bervariasi. Namun kenaikan tersebut hampir sama jumlahnya jika dibandingkan antara kenaikan alokasi pajak
Hutagaol, Winarno dan Pradipta (2007) mengutip Booker (1945) yang menyatakan bahwa orang dengan penghasilan yang tinggi perlu dikenai tarif pajak yang lebih tinggi. Namun dapat terjadi para wajib pajak membagi penerimaannya agar tidak termasuk ke dalam persentase pengenaan pajak yang lebih tinggi (Goolsbee, 2000). Pada kasus 3 dan 4 diatas, kecenderungan ketidak patuhan akan meningkat karena atas penggabungan penghasilan tersebut selisih tarif yang terlalu besar. Cara yang dilakukan oleh wajib pajak adalah dengan tidak melaporkan penghasilan istri sebagai penghasilan gabungan, walaupun istri mempunyai NPWP yang berbeda dengan suami. 
Penerapan sistem pengenaan pajak dengan menempatkan keluarga sebagai satu kesatuan ekonomis meningkatkan beban pajak yang terlalu tinggi dalam kondisi tertentu, yaitu jika pemenuhan kewajiban perpajakan dilakukan secara terpisah. Jika dibandingkan diantara negara anggota ASEAN tarif pajak penghasilan sangat timpang. Struktur tarif pajak penghasilan Orang Pribadi yang mirip dengan Indonesia adalah Negara Thailand dan Vietnam.Dalam kasus istri berpenghasilan dari hanya dari satu pemberi kerja dan mempunyai NPWP individu, dapat mencabut NPWP individu untuk digabungkan dengan NPWP suami. Penghasilan istri dari satu pemberi kerja tersebut akan dianggap sebagai penghasilan yang bersifat final, sehingga tidak digabungkan dengan penghasilan neto suami. Tatacara pencabutan NPWP dapat diunduh pada website www.pajak.go.id.

\section{PENUTUP}

\section{Simpulan}

Tulisan ini bertujuan untuk membahas penerapan perhitungan suami istri yang dianggap memilih perhitungan MT, misalnya dalam kondisi istri berpenghasilan dari satu pemberi kerja namun telah memiliki NPWP dan pada saat pelaporan SPT WPOP tahun 2014 belum mencabut NPWP nya. Selanjutnya atas penggabungan penghasilan suami dan istri, apakah terdapat pengaruh kepada lapisan tarif sesuai pasal 17 UU No. 36 tahun 2008.

Berdasarkan hasil analisa diatas, maka kesimpulannya dalam kondisi istri berpenghasilan dari satu pemberi kerja namun telah memiliki NPWP pada awal tahun dan pada saat pelaporan SPT WPOP tahun 2014 belum mencabut NPWP untuk digabung dengan NPWP suami, dianggap memilih menjalankan hak dan kewajiban perpajakan secara terpisah. Penghasilan neto suami istri dikenai pajak berdasarkan penggabungan penghasilan neto suami-istri dan besarnya pajak yang harus dilunasi oleh msing-masing suami-istri dihitung sesuai dengan perbandingan penghasilan neto mereka.

Mengacu pada hasil eksperimen dan penelitian dari studi literature, terdapat pengaruh peningkatan tariff karena penggabungan penghasilan terhadap kepatuhan wajib pajak.

\section{Saran}

Penggabungan penghasilan suami dan istri, akan terdapat pengaruh kepada lapisan tarif sesuai pasal 17 UU No. 36 tahun 2008. Jika sebelum digabungkan penghasilan kena pajak suami dan istri berada pada lapisan tarif yang berbeda, setelah penghasilan digabungkan, terjadi kurang bayar pada penghasilan gabungan secara bervariasi. Hal ini disebabkan dengan penggabungan penghasilan kena pajak tersebut, pajak yang terhutang berada pada lapisan tarif yang lebih tinggi. Jumlah kurang bayar yang dialoksikan kepada istri sangat signifikan jika sebelum penggabungan penghasilan kena pajak suami berada pada lapisan tarif 3 dan 4, sementara istri pada lapisan 1. Kajian atas tulisan ini hanya dilakukan pada studi literature dan pengamatan pada sekelompok wajib pajak 
dengan lapisan tarif yang berbeda, sehingga masih banyak perbaikan berupa kritik dan saran yang diberikan oleh reviewer). Diharapkan artikel ini dapat dikembangkan dalam bentuk design penelitian dengan populasi yang lebih besar.

\section{DAFTAR PUSTAKA}

Franzoni, L. Alberto (1999). Tax Evasion and Tax Compliance, Encyclopedia of Law \& Economics, 6020 .

Arikunto, Suharsimi. 2006. Prosedur Penelitian Suatu Pendekatan Praktek. Edisi Revisi. Jakarta : PT Rineka Cipta.

Devano Sony, Siti Kurnia Rahayu. 2006. Perpajakan : Konsep, Teori dan Isu. Jakarta : Prenada Media Grup

Media Keuangan. Ayo Bergerak Korps Pajak. http://www.kemenkeu.go,id/ Maret, 2015

Barbuta-Misu, Nicoleta (2011). A Review of Factors for Tax Compliance. Annals of "Dunarea de Jos" University of Galati Fascicle I. Economics and Applied Informatics, XVII

Simon, James. Clinton, Alley. (2004) Tax Compliance, Self Assessment and Tax Administration. Journal of Finance and Management in Public Services, 2. 27-42

Departemen Keuangan Republik Indonesia Direktorat Jenderal Pajak - Strategi Meningkatkan Kepatuhan Wajib Pajak.

http://www.pajak.go.id/content/penerimaan-pajak, 4 Juli 2012

Budi Suryana, Anandita. Mengerek Kepatuhan Wajib Pajak, www.pajak.go.id, 2012

Nurmantu, Safri (2014). Aspek Pajak dalam Menghadapi Masyarakat Ekonomi ASEAN 2015. Artikel dipresentasikan di Seminar Nasional Antisipasi Kebijakan Perpajakan Dalam Menghadapi Asean Economic Community 2015

Komalasari, P.T., \& Nashih, M. (2005). Degree of Tax Payer Compliance and Tax Tariff :The Testing on The Impact of Income Types. Artikel dipresentasikan di Simposium Nasional Akuntansi VIII, Solo, Indonesia.

Organization for Economic and Coorporation Development, Compliance Measurement - Practice Note: $1-23,2001$

Hutagaol, John., Wahyu Wianrno, Wing., Pradipta, Arya. (2007). Strategi Meningkatkan Kepatuhan Wajib Pajak. Jurnal Akuntabilitas. 6, 186-193.

Republik Indonesia, Undang-Undang Nomor 36 tahun 2008 tentang Pajak Penghasilan. Lembaran Negara tahun 2008 